\title{
Additions to the Flora of the Continental Northwest Territories from the Great Slave Lake Area
}

\author{
Paul M. CATling
}

Biodiversity, National Program on Environmental Health, Agriculture and Agri-food Canada, Wm. Saunders Bldg., Central Experimental Farm, Ottawa, Ontario K1A 0C6 Canada; e-mail: catlingp@agr.gc.ca

Catling, Paul M. 2005. Additions to the flora of the continental Northwest Territories from the Great Slave Lake area. Canadian Field-Naturalist 119(3): 437-440.

Eleven species are reported as new to the flora of the continental Northwest Territories. The new native species include Artemesia dracunculus, Chenopodium leptophyllum, Eleocharis erythropoda, Panicum capillare, Schoenoplectus pungens and Symphyotrichum lanceolatum subsp. hesperium var. hesperium. New alien species reported include Achillea ptarmica, Chaenorhinum minus, Galium aparine, Malva neglecta and Silene cserei. Sonchus arvensis, previously reported, is based on material referable to a subsp. uliginosus. Forms new to the flora include Achillea millefolium f. rosea and Actaea rubra $\mathrm{f}$. neglecta. Locations, habitats and distinctive features are provided for the additional taxa. The Hay River lowland ecoregion is a floristically rich area that deserves more botanical exploration.

Key Words: Additions, range extensions, vascular plants, Northwest Territories, Canada.

The flora of the Northwest Territories (NWT) has been extensively studied by many botanists as outlined by Porsild and Cody (1980) with more recent work indicated by Catling et al. (2005*). Four days of studying the flora in southern NWT yielded 11 species not previously recorded. This suggests that either the flora is changing or that parts of the area are understudied, or both. These possibilities are briefly discussed and the additional species are included in an annotated list presented below.

The latitude, longitude, and collection dates for all locations mentioned in the text are indicated in Table 1 and the coordinates are correct to $200 \mathrm{~m}$. In all cases the collector is P. M. Catling. Specimens documenting occurrences are preserved in the Agriculture and AgriFood Canada collection (DAO, see Holmgren et al. 1990 for an explanation of herbarium acronyms) in Ottawa.

\section{Phytogeographic aspects}

Native species

All but one (Chenopodium leptophyllum) of the additional native species are southern plants now reaching their northern limits at Hay River. This region south and west of Great Slave Lake is already known to be a distinctive phytogeographic zone where many southern species reach their northern limits and is also an area where many arctic and alpine plants are absent but otherwise occur throughout NWT (e.g., Raup 1947, page 66 lower figure). The area has been designated as the Hay River lowland ecoregion (number 64) of the Taiga Plain ecozone (Ecological Stratification Working Group 1995). It was designated as the Southern Boreal Province by McJannet et al. (1995).

The climate warming trend in northern Canada will make it possible for plants to extend their distributions

TABLE 1. Locations, habitats, collection dates and latitude and longitude of places in Northwest Territories where additions to the flora were discovered by P. M. Catling in 2003.

\begin{tabular}{|c|c|c|c|}
\hline Habitat and Location & Date & Latitude & Longitude \\
\hline $\begin{array}{l}\text { periodically flooded shore } \\
\text { of Hay River at Hay River }\end{array}$ & 30 July 2003 & 60.4900 & 115.7304 \\
\hline $\begin{array}{l}\text { open vacant land and shoreline } \\
\text { at port of Hay River }\end{array}$ & 30 July 2003 & 60.8214 & 115.7304 \\
\hline $\begin{array}{l}\text { bank of Hay River near West } \\
\text { Channel bridge N side of Hay River }\end{array}$ & 30 July 2003 & 60.8536 & 115.7743 \\
\hline $\begin{array}{l}\text { bulldozed area beside Niven } \\
\text { Lake, } \mathrm{N} \text { side of Yellowknife }\end{array}$ & 30 July 2003 & 62.4603 & 114.3745 \\
\hline vacant lots in Yellowknife & 30 July 2003 & 62.4500 & 114.4300 \\
\hline $\begin{array}{l}\text { open sand prairie, Taltson River } \\
\text { W of Fort Smith }\end{array}$ & 23 July 2003 & 60.3554 & 111.2760 \\
\hline $\begin{array}{l}\text { open rocky ridge, Ingraham Trail, } \\
\text { E of Yellowknife }\end{array}$ & 28 July 2003 & 62.5037 & 114.2764 \\
\hline
\end{tabular}


northward but warming is not likely to be an explanation for new records of native species reported here. Warming to the extent of promoting northward range extension may not have occurred yet and the new native species are easily overlooked in cursory botanical inventory. Consequently they are likely to be longestablished in the area. Unlike the Fort Simpson, Fort Smith and Wood Buffalo areas in the Hay River lowland, the region of Hay River itself has not been sufficiently studied from a botanical viewpoint. There are only few and small collections from the area including those of W. H. Lewis in 1951 (at DAO) reported by Cody (1956) and collections made in 1971 by L. Dahike (at CAN and WAT) and by P. Ducruc, both included in Porsild and Cody (1980). An examination of the maps in Porsild and Cody (1980) indicates that many plants likely to occur in the area have not been recorded.

\section{Introduced species}

There are few published studies of the flora of manmade disturbed habitats such as the Norman Wells pipeline study (Cody et al. 2000). In an unpublished report involving the non-cultivated urban flora of Yellowknife, Steinecke (2001*) gathered information on 135 sites within the city limits. The sampled habitats included roadsides, lawns and vacant lots. A total of 142 species were recorded in the town, $55 \%$ of which were alien. Of these, 25 are additions to the flora (Porsild and Cody 1980; Catling et al. 2005*), including Acer negundo L., Aconitum sp., Alopecurus occidentalis Scribn. \& Tweedy (probably $A$. arundinaceus Sobol which is not new), Amsinckia menziesii (Lehm.) Nels. \& Macbr., Artemesia absinthium L., Campanula rapunculoides L., Dianthus barbatus L., Halenia deflexa (Smith) Giseb., Hordeum vulgare L., Malva rotundifolia L., Panicum miliaceum L. (introduced with bird seed around feeders but possibly not persisting), Portulaca oleracea L., Ranunculus repens L., Rheum rhabarbarum L., Rumex crispus L., Setaria glauca (L.) Beauv., Sonchus uliginosus Bieb., Spiraea cf. betulifolia Pallas and Tropaeolum sp. Since this interesting study is unpublished and there are no specimen vouchers, the records are not accepted as additions, but they are nevertheless of interest and, hopefully, they will be supported by vouchers in the future.

As settlement expands and road traffic increases it is likely that more introduced species will expand into the region by gradual spread along corridors of disturbed habitats such as roads, but also through long distance dispersal by people incidentally transporting soil and seeds on or in vehicles. That such spread of alien species is continuing is suggested by the additional species reported by Steinecke $\left(200^{*}\right.$, listed above) and the five additional alien species reported here. The latter originated from open disturbed sites in either the town of Yellowknife or the town of Hay River. More alien species are expected to enter the region and some may begin to impact native flora and fauna, but with the possible exception of Phalaris canariensis L. (recently reported to be a local problem), there is little evidence of spread into native plant communities.

\section{Annotated List of Additional Species}

Achillea millefolium L. f. rosea Rand. \& Redf.

YARROW (rose-flowered form)

Although the species is well known from NWT, this unusual form with deep rose-purple (instead of white) ligules has not been recorded previously. Found in a bulldozed area beside Niven Lake on N side of Yellowknife, it is occasionally cultivated and likely a garden escape.

\section{Achillea ptarmica $\mathrm{L}$. \\ PEARL YARROW}

Found in an open bulldozed area beside Niven Lake on $\mathrm{N}$ side of Yellowknife, this introduced species differs from A. sibirica Ledeb. in its serrated instead of pectinate leaves and longer ligules to $5 \mathrm{~mm}$. This species is sometimes introduced with "wildflower" seed mixtures.

Actaea rubra (Ait.) Willd. f. neglecta (Gillman) Robins. RED BANEBERRY (white berry form)

This white-fruited form of this native plant is abundant in some parts of the extensive North American range, but previously only "bright red or rarely pink" fruits have been reported for NWT (Porsild and Cody 1980). Several plants were found on a wooded bank of the Hay River near bridge on north side of town.

\section{Artemesia dracunculus L.}

\section{DRAGON WORMWOOD}

This native, linear-leaved species of dry hills and prairies was expected to be discovered in NWT by Porsild and Cody (1980). It was found in open sandy ground on banks of the Hay River at Hay River.

\section{Chaenorhinum minus (L.) Lange \\ DWARF SNAP-DRAGON}

This distinctive, glandular-hairy, introduced plant was frequent in open gravelly areas and along the railway at the port of Hay River. The 5-7 mm flowers are bluish-purple with yellow in the throat.

Chenopodium leptophyllum (Moquin-Tandon) Nuttall ex S. Watson

\section{NARROW-LEAF GoOSEFOOT}

Porsild and Cody (1980) listed this species but excluded it based on the Richardson specimen collected at Fort Franklin on Great Bear Lake "where it was surely an ephemeral introduction." Clements and Mosyakin (2003) show its occurrence in Alberta near the NWT border but not in NWT. It was found on a disturbed sandy portion of an open prairie slope adjacent to the Taltson River east of Fort Smith. At this location it occurred around an open sandy blowout on dry, open, south-facing slopes dominated by Carex siccata Dewey with Calamagrostis purpurascens R. Brown and many other native species of dry, open ground, including Agrostis scabra Willdenow, Arabis holboellii Horne- 
man, Anemone multifida Poiret and Pinus banksiana Lamb. It was also found on top of a rocky ridge $E$ of Yellowknife. This was also a natural, open and rather dry plant community dominated by native species, including Androsace septentionalis L., Arctostaphylos uva-ursi (L.) Spreng., Artemesia hyperborea Rydb., Calamagrostis purpurascens R. Br., Carex supina Willd., Juniperus communis L., Juniperus horizontalis Moench, Rosa acicularis Lindl., Saxifraga tricuspidata Ait. and Senecio pauperculus Michx. The flora was entirely native and had not been disturbed by man. Consequently Chenopodium leptophyllum is considered native.

\section{Eleocharis erythropoda Steudel \\ BALD SPIKE-RUSH}

Frequent on the periodically flooded shore of the Hay River at Hay River, this native plant was reported for the Northwest Territories by Smith et al. (2002) but accidentally omitted from the recent compilation of additions (Catling et al. 2005*) so included here. It differs from E. palustris (L.) Roemer \& Schultes by the basal scale completely or nearly surrounding the stem (instead of encircling only $2 / 3$ ) and relatively narrow stems 0.3-1.4 mm thick (instead of 0.5-5 mm thick). See under "Panicum capillare" for associated species.

\section{Galium aparine L. \\ Cleavers}

Found in vacant lots and disturbed open places in Yellowknife, this species differs from G. triflorum by the retrorse barbs on leaves and stems. There are possibly both native and introduced races; the plant of open disturbed sites is probably introduced.

Malva neglecta Wallr.

DWARF MALLOW

A few plants of this introduced species were found in vacant lots in Yellowknife. This is the first report of a species of Malva in NWT. The rounded leaves and axillary flowers with petals twice as long as the sepals are distinctive.

\section{Panicum capillare L. var. occidentale Rydberg COMMON PANIC GRASS}

This is the first report of a species in this genus for NWT. The exerted panicles and long-acuminate spikelets, many with pedicels shorter than the spikelet, suggested var. occidentale. The plants were sporadic on the periodically flooded shore of the Hay River at Hay River. A native species, it often occurs in disturbed sites and is sometimes thought to be an introduction, but on the periodically flooded shoreline it occurred with a diversity of native species in one of its characteristic natural habitats. Close plant associates included Aster modestus Lindl., Caltha natans Pall., Carex sychnocephala Carey, Cicuta maculata var. angustifolia Hook., Deschampsia caespitosa (L.) Beauv., Eleocharis erythropoda Steud., Galium triflorum Michx., Gnaphalium uliginosum L., Juncus nodosus L., Limosella aquatica L., Poa palustris L., Potentilla anserina L.,
Ranunculus scleratus L., Ranunculus macounii Britt., Rorippa palustris (L.) Besser, Rumex maritimus L., Schoenoplectus pungens (Vahl) Palla, Scirpus microcarpus Presl and Spartina gracilis Trin.

Schoenoplectus pungens (Vahl) Palla

(Scirpus americanus auct. non Persoon)

COMmon Three-SQuare BULRISH

This native plant was frequent along the periodically flooded shore of Hay River at Hay River. It is distinctive in the lateral (instead of terminal) inflorescence with stemless spikelets and the sharply three-angled stems. This occurrence may be an extension of known range of approximately $700 \mathrm{~km}$ based on Packer's (1983) map. See under "Panicum capillare" for associated species.

Silene cserei Baumg.

BALKAN CATCHFLY

Found along the railway and in adjacent open sandy soil at port of Hay River, this tall introduced species (2-8 dm) has 3 styles, lacks glutinous bands on the stem and is without an inflated calyx.

Symphyotrichum lanceolatum (Willd.) G. L. Nesom subsp. hesperium (Gray) Nesom var. hesperium (Aster lanceolatus Willd. subsp. hesperius (A. Gray) Semple \& Chmielewski, Aster hesperius A. Gray)

\section{WESTERN WILLOW ASTER}

This native plant was found on the periodically flooded shore of Hay River at Hay Riverand at the port of Hay River. At least 100 plants were seen and they had either white or blue ray flowers. This species has green leaves 5-15 mm wide instead of purplish-green leaves less than $5 \mathrm{~mm}$ wide as in A. borealis (T. \& G.) Prov. (previously A. junciformis Rydberg). Unlike A. spathulatus Lindley, the stems are pubescent. This species is well known from the Lake Athabasca area of northern Alberta.

\section{Additional Notes}

Sonchus arvensis L. subsp. uliginosus (Bieb.) Nyman (S. arvensis var. glabrescens Guenth., Grab. \& Wimmer, S. uliginosus Bieb.)

This introduced species is frequent in disturbed sites at Hay River and Yellowknife, but is not an addition because the inclusion of "Sonchus arvenvis L." in Porsild and Cody (1980) is not based on material of subsp. arvensis but rather on material referable to this variety (based on examination of specimens collected at Hay River (Cody 14839, DAO) and on the Mackenzie highway (Thieret 6172, DAO).

\section{Acknowledgments}

Suzanne Carriere, Ecosystem Management Biologist, Wildlife \& Fisheries Division, Department of Resources, Wildlife \& Economic Development, provided extensive help and support. Bill Cody, Curator Emeritus, with AAFC in Ottawa provided essential information and comments on the manuscript. Deborah Johnson and Mike Fournier assisted with plant collecting. 
Documents Cited (marked $*$ in text)

Catling, P. M., W. J. Cody, and G. Mitrow. 2005. A compilation of additions to the flora of the continental portions of Northwest Territories and Nunavut. Botanical Electronic News 353. www.ou.edu/cas/botany-micro/ben/ben353.html.

Steinecke, K. 2001. Urban flora and plant communities in subarctic settlements: two case examples from Yellowknife, Canada, and Reykjavik, Iceland. University of Bremen, Bremen, Germany. 34 pages.

\section{Literature Cited}

Clements, S. E., and S. L. Mosyakin. 2003. Chenopodium Linnaeus. Pages 275-299 in Flora of North America Editorial Committee, eds. Flora of North America. Volume 4, Magnoliophyta: Caryophyllidae, part 1. Oxford University Press, New York.

Cody, W. J. 1956. New plant records for northern Alberta and southern Mackenzie District. Canadian Field-Naturalist 70: 101-130.

Cody, W. J., K. L. MacInnes, J. Cayouette, and S. Darbyshire. 2000. Alien and invasive native vascular plants along the Norman Wells Pipeline, District of Mackenzie, Northwest Territories. Canadian Field-Naturalist 114: 126137.

Ecological Stratification Working Group. 1995. A National Ecological Framework for Canada. Agriculture and Agri-
Food Canada, Research Branch, Centre for Land and Biological Resources Research and Environment Canada, State of the Environment Directorate, Ecozone Analysis Branch, Ottawa. Report and National Map at 1:7 500000 scale.

Holmgren, P. K., N. H. Holmgren, and L. C. Barnett. 1990. Index herbariorum, part 1. The herbaria of the world. New York Botanical Garden. Bronx, New York. 693 pages.

McJannet, C. L., G. W. Argus and W. J. Cody. 1995. Rare vascular plants in the Northwest Territories. Canadian Museum of Nature Syllogeus (73). 104 pages.

Packer, J. G. 1983. Flora of Alberta. Second edition, revised. University of Toronto Press, Toronto. 687 pages.

Porsild, A. E., and W. J. Cody. 1980. Vascular plants of continental Northwest Territories. National Museums of Canada, Ottawa. 667 pages.

Raup, H. M. 1947. The botany of southwestern Mackenzie. Sargentia 6: 1-275.

Smith S. G., J. J. Bruhl, M. S. González-Elizondo, and F. J. Menapace. 2002. 7. Eleocharis. Pages 60-120 in Flora of North America Volume 23, Magnoliophyta: Commelinidae, (in part): Cyperaceae. Edited by Flora of North America Editorial Committee, Oxford University Press, New York.

Received 31 March 2005

Accepted 1 September 2005 
LAS LEIGHTON - Diet of Great Horned Owl in the Creston Valley, British Columbia, 1998-2005 (Linda M. Van Damme - NOTES: Anti-predator behaviour by a Mule Deer to Coyotes in Vernon, British Columbia (Chris Siddle) - Attempted capture of a Red-legged Frog by an American Robin (Michael I. Preston) - Evidence of an unusual prey item in a Barred Owl pellet (Christian W. Gronau) - Northernmost nest record of the Flammulated Owl (Otus flammeolus) in Canada (Karen L. Wiebe - First nesting record of Say's Phoebe (Sayornis saya) in the East Kootenay, British Columbia (Robert S. Ferguson and Mark Dascher) - Current status of the Blackthroated Blue Warbler in British Columbia (Gary S. Davidson - Field observations of Gray Flycatchers breeding at Summerland, British Columbia, 1988-2005 (I. Laurie Rockwell) - American Crow predation in an Eared Grebe nesting colony at Rawlings Lake, British Columbia (Chris Siddle)

\section{Errata The Canadian Field-Naturalist 119(3)}

Catling, Paul M. 2005 [2006]. Additions to the flora of the continental Northwest Territories from the Great Slave area. Canadian Field-Naturalist 119(3): 437-440.

(page 438) Actaea rubra f. neglecta: This form had previously been reported by Cody 1961. Canadian Field-Naturalist 75(2): 62 from Fort Simpson. Michael Oldham (Ontario Ministry of Natural Resources) reports confirming its presence there in August 2007.
- SPECIES OF REGIONAL SIGNIFICANCE: Canvasback Fort St. John (Chris Siddle) - Bobolink - Nakusp to Edgewood (Gary S. Davidson) - WILDLIFE DATA CENTRE: Featured species - Turkey Vulture (R. Wayne Campbell, Michael I. Preston, Linda M. Van Damme, and Diann MacRae - BRITISH COLUMBIA ROUND-UP: Field notes and caring people - News of Friends - From the archives Final flight - Publications of interest [Compiled and edited by Chris Siddle] - Announcements and meetings.

Annual memberships in the Biodiversity Centre for Wildlife Studies (which included Wildlife Afield are $\$ 30$ (individual), $\$ 40$ (family). \$20 (student), \$500 (life). Biodiversity Centre for Wildlife Studies, PO Box 6218, Station C, Victoria, British Columbia V9P 5L5 Canada. Tel/Fax: 250-477-0465; e-mail: editor@wildlifebc.org

(page 449) Sonchus arvennsis subspecies uliginosus : Thiert reported this in 1963 Sida 1(3): 169 as S. arvensisvar. glabrescens from the Yellowknife Highway (Hwy 3).

My appreciation to Michael Oldham for bringing these to my attention.

PAUL M. CATLING Agriculture and Agri-Food Canada Ottawa, Ontario 